\title{
EXPERIMENTAL STUDY OF HIGH STRENGTH CONCRETE OF M90 GRADE USING UNPROCESSED FLY ASH AND SILICA FUME
}

\author{
Ajit R. Sapkal ${ }^{1}$, Alankar V. Jadhav ${ }^{2}$, M.V. Nagendra ${ }^{3}$ \\ ${ }^{1}$ Student, Civil Engineering Department, P.V.P.I.T. Budhgaon, Sangli Maharashtra India \\ ${ }^{2}$ Student, Civil Engineering Department, P.V.P.I.T. Budhgaon, Sangli Maharashtra India \\ ${ }^{3}$ Professor Civil Engineering Department, P.V.P.I.T. Budhgaon, Sangli Maharashtra India
}

\begin{abstract}
Concrete is the most widely used construction material in overall world due to its various advantages in the infrastructural industries. The production of cement causes atmospheric and environmental pollution by emitting carbon dioxide into the atmosphere. Pozzolonic by products from electrical industries are supplimentory cementitious materials such as GGBS, fly ash, slag, Rice Husk are utilized in recent years as cement alternative material for growing HSC with progressed workability, energy and durability with decreased permeability. High strength concrete (HSC) is made with adding mineral admixtures like silica fume, fly ash in the concrete. Using cementitious materials such as unprocessed fly ash and silica fume in the High strength concrete mix gives benefits in various ways. Also these materials reduces emission of carbon dioxide in the atmosphere. So that, It gives an environment friendly concrete for the sustainable development. Preparing high strength concrete by using these cementitious materials with super plasticizers gives required strength.
\end{abstract}

Key Words: fly ash, silica fume, super plasticizer, unprocessed fly ash,

\section{INTRODUCTION}

High strength concrete (HSC) is a developing concrete that will allow the civil, infrastructure and defence construction industry effectively material use, generating economic benefits and build structures that are strong, durable, and sensitive to man-made and environmental hazards. It is used in civil applications where impact resistance, high durability and structure size are governing factors in design. The current work focuses on achieving high compressive strength of HSC by practical execution of percentage content of materials like silica fume, fly ash, fine aggregate coarse aggregate and admixture. This work is carrying out to study the mix design of high strength concrete with addition of unprocessed fly ash and silica fume in various proportions. We propose the mix proportion of M90 in terms of cement, fine aggregates and coarse aggregates including fly ash and silica fume percentage by replacing of cement and super plasticize percentage by replacing of water.

\subsection{Objectives and significance}

The main focus of this project is to reduce the cement content by fly ash and super plasticiser so that, there is low emission of $\mathrm{CO} 2$ in environment. Industrial waste such as fly ash, this waste used in construction can minimize pollution in environment. Due to cement, large amount of $\mathrm{CO} 2$ emits, with help of fly ash the percentage of $\mathrm{CO} 2$ Reduce. For the higher strength, there is requirement of large amount of cement content. Addition of silica fume and fly ash reduces cement at required concrete strength.

\section{CONSTITUENTS}

The constituents usually used in the high strength concrete mixes are cement, fine aggregate, coarse aggregate, superplasticizer, low water-cement ratio and mineral admixtures such as fly ash, silica fume, etc. As proper mix designs are not available for M90 grade high strength concrete till date, trial mixes are very important in achieving the designed concrete properties. Knowing the effect of each material on the fresh as well as hardened concrete helps a lot in selecting the proportion in the trial mixes. Thus, the current research summarises the outcome of the infrastructural study of material and application of the materials in developing a high strength concrete mix by taking compressive strength test. Low W/C ratio is required for low permeability of concrete, which is important for high durability.

- Cement

- Fine aggregate

- Coarse aggregate

- Super plasticizer

- Fly Ash

- Silica Fume:

- Water

\section{CONCRETE AND ENVIRONMENT}

Concrete is the main key structural material in the human era. With the development of modern civilization concrete become more important material in constructions. In present time concrete is the most widely used construction materials. It is difficult to point out another material of construction which is as versatile as concrete. It is the material of choice where strength, permanence, durability, impermeability, fire resistance and abrasion resistance are required. It is so closely associated now with every human activity that it touches every human being in his day to day living. As written by Brunauer "Development that meets the needs of the present without compromising the ability of future generations to meet their own needs. However, the development of modern concrete industry also introduces many environmental problems such as pollution, waste dumping, emission of dangerous gases, 


\section{International Journal of Engineering Applied Sciences and Technology, 2021 \\ Vol. 6, Issue 5, ISSN No. 2455-2143, Pages 172-174 \\ Published Online September 2021 in IJEAST (http://www.ijeast.com)}

depletion of natural resources etc. With the beginning of the 21 st century, the public shift their focus towards sustainable development (SD). This means that, in future, to pursue techno-economic goals without assigning equal importance the goal of ecological balance on the planet earth will be quiet impossible.

\section{METHODOLOGY}

In this investigation we replace the cement with mineral admixture such as unprocessed fly ash, Silica fume in various percentages. By taking minimum water cement ratio, mix design is prepared. Here, super plasticizer is used for better workability. By using cube of $150 \times 150 \times 150 \mathrm{~mm}$ size, different concrete mixes are casted and compressive test is conducted to find compressive strength after 7 days and 28 days curing period.

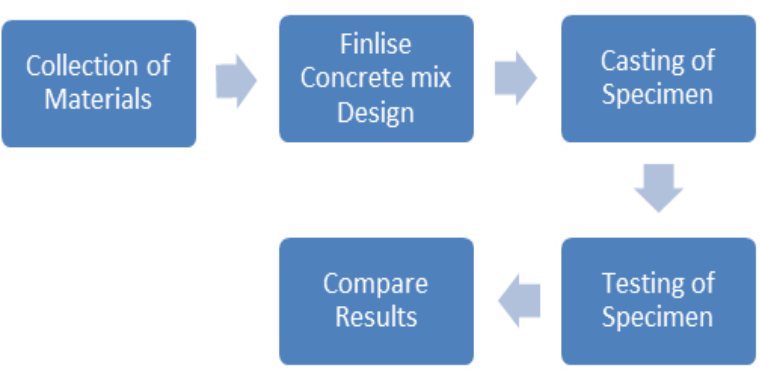

Chart 1: Methodology chart

\section{CONCRETE MIX DESIGN}

Mix design is prepared with, $15 \%$ fly ash, $5 \%$ silica fume of total weight of cementitious material and $0.5 \%$ super plasticizer.

\subsection{Mix proportion for M90 concrete:}

- $\quad$ Cement $=594 \mathrm{~kg} / \mathrm{m} 3$

- $\quad$ Fly ash = $111.37 \mathrm{~kg} / \mathrm{m} 3$

- $\quad$ Silica Fume $=37.125 \mathrm{~kg} / \mathrm{m} 3$

- Water $=162 \mathrm{~kg} / \mathrm{m} 3$

- $\quad$ Fine Aggregate $=507.16 \mathrm{~kg} / \mathrm{m} 3$

- $\quad$ Coarse Aggregate $=1042.49 \mathrm{~kg} / \mathrm{m} 3$

- Admixture $=3.44 \mathrm{lit} / \mathrm{m} 3$

$$
\text { Material quantity per cu. M }
$$

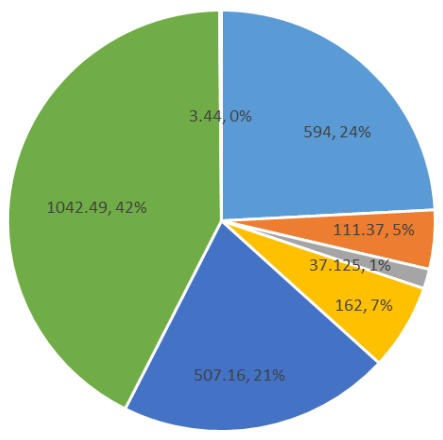

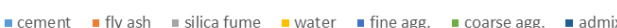

Chart 2 : Material quantity for M90 concrete

\section{STRENGTH COMPARISON AND RESULT}

Here, For M90 grade concrete we use two types of super plasticizers such as, Aadmix 389 and Aadmix 345R respectively at same content in two trial mixes. Strength of both trial mixes are following.

\subsection{M90 grade concrete $\left(1^{\text {st }}\right.$ trial $)$ :}

Table $1: 7$ Days Strength of M90 concrete

\begin{tabular}{|l|l|l|l|l|}
\hline Strength & $\begin{array}{l}\text { Weight } \\
\text { in Kg }\end{array}$ & $\begin{array}{l}\text { Strength } \\
\mathrm{MPa}\end{array}$ & $\begin{array}{l}\text { Peak } \\
\text { Load in } \\
\text { KN }\end{array}$ & $\begin{array}{l}\text { \% } \\
\text { Strength }\end{array}$ \\
\hline & 8.970 & 48.88 & 1099.8 & 54.31 \\
\hline M90 & 9.120 & 48.88 & 1099.8 & 54.31 \\
\hline & 8.890 & 52.4 & 1179 & 58.22 \\
\hline
\end{tabular}

Average strength $=50.05 \mathrm{MPa}$

Table 2 : 28 Days Strength of M90 concrete

\begin{tabular}{|c|c|c|c|c|}
\hline Strength & $\begin{array}{c}\text { Weight } \\
\text { in Kg }\end{array}$ & $\begin{array}{c}\text { Strength } \\
\mathrm{MPa}\end{array}$ & $\begin{array}{c}\text { Peak } \\
\text { Load in } \\
\text { KN }\end{array}$ & $\begin{array}{c}\% \\
\text { Strength }\end{array}$ \\
\hline & 9.235 & 62.9 & 1417.4 & 69.89 \\
\hline M90 & 8.970 & 60.7 & 1365.8 & 67.44 \\
\hline & 8.985 & 61.6 & 1386.9 & 68.44 \\
\hline
\end{tabular}

Average strength : $61.73 \mathrm{MPa}$

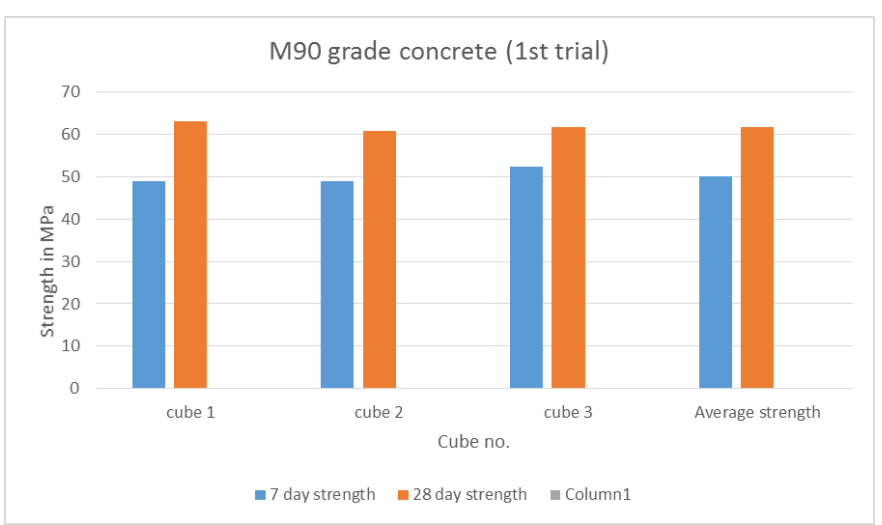

Chart 3 : strength of M90 concrete ( $1^{\text {st }}$ trial $)$

6.2 M90 grade concrete $\left(2^{\text {nd }}\right.$ trial $)$ :

Table 3 : 7 Days Strength of M90 concrete

\begin{tabular}{|c|c|c|c|c|}
\hline Strength & $\begin{array}{c}\text { Weight } \\
\text { in Kg }\end{array}$ & $\begin{array}{c}\text { Strength } \\
\mathrm{MPa}\end{array}$ & $\begin{array}{c}\text { Peak } \\
\text { Load in } \\
\mathrm{KN}\end{array}$ & $\begin{array}{c}\% \\
\text { Strength }\end{array}$ \\
\hline & 8.870 & 66.9 & 1507.3 & 74.33 \\
\hline M90 & 8.960 & 64.1 & 1444.2 & 71.22 \\
\hline & 8.785 & 62.5 & 1407.3 & 69.44 \\
\hline
\end{tabular}

Average strength : $64.5 \mathrm{MPa}$ 
International Journal of Engineering Applied Sciences and Technology, 2021

Vol. 6, Issue 5, ISSN No. 2455-2143, Pages 172-174

Published Online September 2021 in IJEAST (http://www.ijeast.com)

Table 4 : 28 Days Strength of M90 concrete

\begin{tabular}{|c|c|c|c|c|}
\hline strength & $\begin{array}{c}\text { Weight } \\
\text { in Kg }\end{array}$ & $\begin{array}{c}\text { Strength } \\
\mathrm{MPa}\end{array}$ & $\begin{array}{c}\text { Peak load } \\
\text { in KN }\end{array}$ & $\begin{array}{c}\% \\
\text { Strength }\end{array}$ \\
\hline & 9.015 & 88.4 & 1989 & 98.22 \\
\hline M90 & 8.990 & 90.35 & 2032.87 & 100.38 \\
\hline & 9.100 & 89.05 & 2003.62 & 98.94 \\
\hline
\end{tabular}

Average strength : $89.27 \mathrm{MPa}$

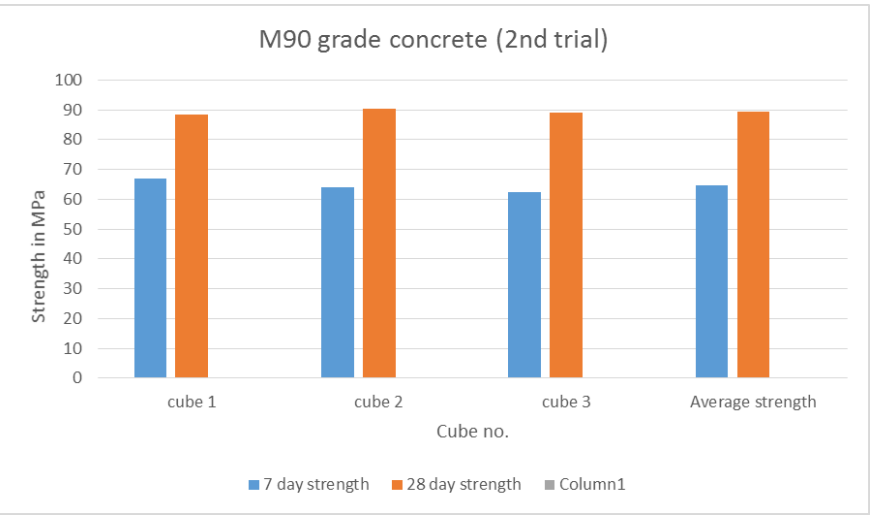

Chart 4 : strength of M90 concrete ( $2^{\text {nd }}$ trial)

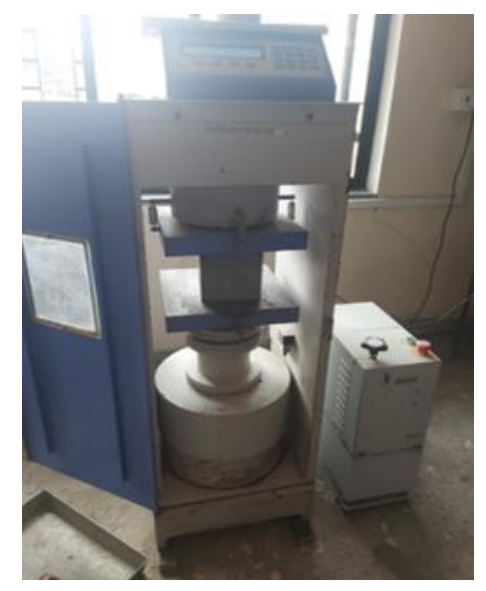

Fig -1 : Testing of Concrete cubes

\section{CONCLUSIONS}

The observation and results obtained from experimental programme, this study can be concluded as,

- For high strength concrete mix, $15 \%$ replacement of fly ash, $5 \%$ silica fume by cement with $0.5 \%$ admixture gives required compressive strength at 28 days.

- The Fly ash can be effectively used and also we can control the air pollution by reducing $\mathrm{CO} 2$ percent from atmosphere and minimizing cement producing industries. So, It becomes ecofriendly concrete.

- High strength concrete has excellent properties and is well suited to various infrastructural fields.

- Waste pozzolonic materials such as fly ash, silica fume are most important building material for the sustainable construction and consumption of large volumes of fly ash.

- The use of fly ash, silica fume and super plasticizer in High strength concrete gives better results after testing.

- There is reduction in quantity of cement to get the design strength so that saving in the cost of cement. The use of super plasticizers gives sufficient workability to High strength concrete at minimum water, there is saving of water.

\section{REFERENCES}

1. "Investigation of High-Strength Concrete Using Fly Ash and Silica Fume" by Dr. Rakesh Srivastava1, Yogendra Kumar, Rupesh Kumar, Saurabh Kumar, Sonam Gupta, Vijay Kumar and Vividh Mahajan

2. "Effect of fly ash on mechanical properties of high strength concrete" by Bharat kumara naik T, J.M. srishaila, Rajendra kumar K. M, Veerangouda R.

3. "Study on Strength Development of High Strength Concrete Containing Fly ash and Silica fume" by A.R. Hariharan, A. S. Santhi and Mohan Ganesh.

4. "Experimental Study of High Strength Concrete (M70) Using Manufactured Sand" by Karishma M. Sheikh, Mandar M. Joshi

5. "Characterization of fly ash for their effective management and utilization" By Rakesh Kumar Behera, National Institute of Technology Rourkela, Orissa - 769008

6. "High Strength Concrete: Effects of Materials, Curing and Test Procedures on Short-Term Compressive Strength" Catherine W. French, Alireza Mokhtarzadeh

7. "Design Guide of High Strength Concrete" Website: www.bca.gov.sg/academy

8. Book - "Concrete Technology" by M. S. Shetty.

9. Book - "Optimizing the use of Fly ash in concrete" by Michael Thomas, Ph.D., Professor of Civil Engineering, University of New Brunswick 